\title{
Persepsi Wisatawan Terhadap Potensi Pariwisata Olahraga Wahana Canyoning
}

\author{
I Gede Yana $^{1 *}$, I.K. Budaya Astra ${ }^{2}$, I.G. Suwiwa ${ }^{3}$ iD \\ ${ }^{123}$ Program Studi Penjaskesrek, Jurusan Pendidikan Olahraga Universitas Pendidikan Ganesha, Singaraja Indonesia \\ *Corresponding author: yanaghen99@gmail.com
}

\begin{abstract}
Abstrak
Kurangnya promosi serta kelengkapan fasilitas di tempat wisata, menjadi salah satu faktor timbulnya kesenjangan antara pariwisata diberbagai wilayah. Oleh karena itu harus dicari solusi untuk mengatasi masalah ini. Penelitian ini bertujuan untuk mengetahui informasi mengenai potensi serta daya tarik pariwisata olahraga yang ada di Gitgit Waterfall dan informasi mengenai wahana yang ada di Gitgit Waterfall. Penelitian ini merupakan deskriptif kuantitatif dengan jenis survei. Populasi pada penelitian ini wisatawan yang pernah mengunjungi Gitgit waterfall. Sampel dalam penelitian ini menggunakan non-probability sampling dengan teknik accidental sampling dengan jumlah 95 orang. persepsi intrinsik bila dipersentasekan memperoleh persentase $85,9 \%$, bila dikonversikan pada tabel skala penilaian katagori persepsi intrinsik dalam katagori sangat baik. Pernyataan persepsi ekstrinsik bila dipersentasekan memperoleh persentase $84,6 \%$ bila dikonversikan pada tabel skala penilaian katagori persepsi ekstrinsik dalam katagori sangat baik. pada indikator sarana prasarana memperoleh persentase $87 \%$ dalam penilaian katagori sangat baik. Hasil persepsi wisatawan terhadap potensi pariwisata olahraga wahana canyoning di Gitgit Waterfall memperoleh 85,5\% dengan katagori sangat baik. Di Simpulkan bahwa daya tarik wisatawan terhadap olahraga wahana canyoning sangat baik, dan Wisatawan mendapat informasi secara cepat, baik menggunakan media sosial (instagram, facebook dan media sosial lainnya) adapun media pemasaran lain (pampfet, benner, dan media cetak). Untuk saran perlu ditingkatkan lagi dalam segi pengelolaannya agar lebih baik.
\end{abstract}

Kata Kunci : Persepsi, Pariwisata, Canyoning

\section{Abstract}

The lack of promotion and completeness of facilities at tourist attractions is one factor that causes the gap between tourism in various regions. Therefore, a solution must be found to overcome this problem. This study aims to find out information about the potential and attractiveness of sports tourism at Gitgit Waterfall and information about rides at Gitgit Waterfall. This research is a quantitative descriptive with a survey type. The population in this study were tourists who had visited the Gitgit waterfall. The sample in this study used non-probability sampling with an accidental sampling technique with 95 people. Intrinsic perception when presented is $85.9 \%$ when converted to the rating scale table for the intrinsic perception category. Therefore, it is in the very good category. When presented, statements of extrinsic perception get a percentage of $84.6 \%$ when converted to the rating scale table for the extrinsic perception category in the very good category on the indicator of infrastructure obtained a percentage of $87 \%$ in assessing the very good category. The results of tourists' perceptions of the tourism potential of canyoning rides at Gitgit Waterfall obtained $85.5 \%$ in the very good category. It is concluded that the attraction of tourists to the sport of canyoning is very good, and tourists get information quickly, both using social media (Instagram, Facebook, and other social media) and other marketing media (pamphlets, banners, and print media). For suggestions need to be improved again in terms of management so that it is better.

Keywords: Perception, Tourism, Canyoning

$\begin{array}{ll}\text { History: } & \text { Publisher: Undiksha Press } \\ \text { Received: 24 April } 2021 & \text { Licensed: This work is licensed under } \\ \text { Revised: } 1 \text { Mei } 2021 & \text { acreative Commons Attribution 3.0 License } \\ \text { Accepted: } 26 \text { Mei } 2021 & \text { C) } \\ \text { Published: 29 Juni } 2021 & \end{array}$




\section{Pendahuluan}

Pada saat ini kepariwisataan di Indonesia telah tumbuh dan berkembang menjadi salah satu pemasukan devisa bagi negara. Hal tersebut dapat terjadi karena Indonesia memiliki potensi yang besar di sektor pariwisata. Ini bisa dilihat dari indahnya berbagai macam pemandangan alam, kebudayaan, sejarah bangsa, festival- festival atau upacaraupacara daerah yang unik, berbagai macam seni lukis, kerajinan tangan, dan banyaknya tempat yang sangat menarik bagi para wisatawan mancanegara yang ingin mengunjungi destinasi wisata di setiap daerahnya (Sutiani, 2018).

Indonesia merupakan salah satu negara yang memiliki pulau terbanyak, oleh karena itu Indonesia juga menyandang sebutan pulau seribu, pulau-pulau tersebut terpisahkan oleh lautan sehingga wilayah Indonesia memiliki wilayah pesisir dan lautan yang sangat luas dengan berbagai macam sumberdaya yang ada didalamnya. Salah satu pulau di Indonesia yang kaya akan keindahan sumberdaya alamnya adalah Bali, keindahan sumberdaya alam Bali sampai saat ini masih sangat terkenal sebagai salah satu destinasi pariwisata di dunia, walaupun demikian perkembangan pariwisata di Bali mengalami kesenjangan yang sangat tinggi, yaitu pengembangan pariwisata di Bali Utara seperti Buleleng tidak sepesat perkembangan pariwisata di Bali Selatan seperti kawasan Kuta, Nusa Dua, Sanur dan sekitarnya (Amanah,2006).

Padahal jika dilihat potensi pariwisata di Bali Utara tidak kalah dengan potensi wisata di Bali Selatan, oleh karena itu diperlukan adanya pengembangan pariwisata yang memperhatikan aspek keberlanjutan dan kelestarian di kawasan Bali Utara. Melihat potensi sumberdaya yang dimilki oleh pesisir pantai Bali Utara seperti hutan mangrove, pantai berpasir, ekosistem perikanan dan terumbu karang makan kegiatan yang dapat dikembangkan adalah ekowisata pesisir, karena ekowisata merupakan kegiatan wisata yang berlandaskan pada aspek konservasi lingkungan (Purwita, 2018).

Bali sebagai salah satu destinasi terpopuler di Indonesia dapat dikatakan sebagai leading sector perekonomian masyarakat Bali yang secara langsung ataupun tidak langsung mayoritas masyarakat Bali mengantungkan hidupnya pada industri pariwisata. I Nyoman Sirtha menyebutkan bahwa pembangunan industri pariwisata menjadi prioritas utama disamping pertanian dan industri kecil. Pariwisata mampu menstimulasi sektor-sektor produktifitas pendukung pariwisata lainnya. Pada tahun 2019 Bali mencatat kunjungan wisatawan mancanegara sebesar 6,28 juta kunjungan dengan pertumbuhan sebesar 3,37\%, secara total ekonomi Bali di tahun 2019 tercatat tumbuh 5,63 persen (Yanti, 2021).

Kabupaten Buleleng sebagai daerah tujuan wisata memiliki beberapa kelemahan, sehingga wisatawan yang berkunjung relatif kecil bila dibandingkan dengan daerah lain yang berada di bagian selatan pulau Bali. Kelemahan-kelemahan tersebut diantaranya jarak ke ibu kota propinsi dan bandara udara yang cukup jauh, jalan yang berliku dan kurang tepatnya strategi promosi wisata. Terlebih lagi melihat sejarah Bali yang dahulu Ibu Kota Propinsi terletak di Kabupaten Buleleng termasuk menjadi pintu masuk bagi orang asing melalui pelabuhan laut, sesungguhnya Kabupaten Buleleng telah dikenal oleh wisatawan dari tahun 1920an (Diparda, 2003).

Padahal sesungguhnya Kabupaten Buleleng memiliki banyak daya tarik wisata alam dan budaya yang dapat dikemas ke dalam berbagai jenis paket wisata seperti wisata spiritual dan ekowisata yang sedang disegani oleh wisatawan, terutama wisatawan manca negara. Konsep dan implementasi rill pada pariwisata dan industri kreatif memiliki kaitan yang sangat erat. Keduanya saling mendukung dan ketiadaan salah satunya akan menyebabkan ketimpangan dalam menciptakan daya saing yang komprehensif (Nirwandar, 2014). Pertumbuhan industri kreatif dan sinergi baru yang dibuat dengan sektor lain menawarkan 
kesempatan yang menarik, termasuk untuk sektor pariwisata (Sahara, 2016), (Widiastini, 2012)

Pariwisata merupakan suatu keseluruhan elemen-elemen terkait yang didalamnya terdiri dari wisatawan, daerah tujuan wisata, perjalanan, industri dan lain sebagainya yang merupakan kegiatan pariwisata. Pariwisata menjadi andalan utama sumber devisa karena Indonesia merupakan salah satu Negara yang memiliki beraneka ragam jenis pariwisata, misalnya wisata alam, sosial maupun wisata budaya yang tersebar dari Sabang hingga Merauke. Selain menyimpan berjuta pesona wisata alamnya (Devy, 2017)

Pariwisata adalah paradigma baru khususnya bagi pemerintahan Indonesia dalam hal meningkatkan perekonomian serta mendongkrak popularitas suatu negara dan daerah. Di Indonesia sendiri mempunyai berbagai macam jenis hal yang dapat dijadikan sebagai objek wisata, mulai dari sektor laut yang sangat luas dan keindahan daratnya. Semua itu dapat dijadikan peluang yang sangat besar sebagai peningkatan perekonomian.

Ketika suatu negara memiliki objek atau sektor yang bisa dibanggakan dan dapat berpeluang pesat maka hal tersebut bisa menjadi ujung tombak untuk memajukan daya saing dari segi perekonomian sebuah negara tersebut. Maka dari itu pariwisata merupakan sektor yang terus berkembang pesat bahkan menjadi sektor andalan Indonesia. Bahkan Pemerintah Indonesia telah menetapkan target 20 juta kunjungan wisatawan ke Indonesia pada tahun 2020. Oleh karena itu, dalam rangka mencapai target dan mengembangkan sektor pariwisata, perlu adanya upaya dalam pembangunan pariwisata di Indonesia.

Adapun berbagai macam alternatif yang dapat dikembangkan dari sektor pariwisata di Indonesia, yaitu dari segi pariwisata olahraga (sport tourism), karena selain wisatawan dapat berlibur dengan tujuan kepuasan batin wisatawan juga secara tidak langsung bergerak dan berolahraga. Jadi, alternatif dari segi pariwisata olahraga tersebut sangat dapat memberikan dampak yang sangat positif terhadap wisatawan yang berkunjung di tempat wisata. Menurut Gamal (1997:4), wisatawan (tourist) adalah pengunjung yang tinggal sementara, sekurangkurangnya 24 jam di suatu negara.

Sedangkan pelancong (excusionist) adalah pengunjung sementara yang tinggal di suatu negara yang dikunjungi dalam waktu kurang dari 24 jam. Wisatawan juga pelancong yang melakukan perjalanan rekreasi ke tempat wisata yang mereka inginkan dengan tujuan mendapatkan kepuasan diri sendiri baik dari segi lahir maupun batin. Sedangkan pengertian wisatawan menurut organisasi pariwisata dunia adalah seorang yang melakukan perjalanan paling tidak sejauh $80 \mathrm{~km}$ (50 mil) dari rumahnya dengan tujuan rekreasi. Ada dua macam wisatawan yaitu wisatawan asing/mancanegara dan wisatawan domestik, wisatawan asing yaitu wisatawan yang berasal dari luar negeri atau dari negara tertentu yang datang berkunjung ke negara lain dari luar negaranya, sedangkan wisatawan domestik (wisatawan dalam negeri atau wisatawan nusantara) yaitu wisatawan atau seseorang yang asli dalam negerinya dan berkunjung ke negerinya atau daerah dari negaranya sendiri atau juga kegiatan kepariwisataan yang ruang lingkupnya terbatas pada tempat tertentu saja.

Pariwisata olahraga merupakan paradigma baru dalam pengembangan pariwisata dan olahraga di Indonesia. Olahraga dan pariwisata adalah gabungan aktivitas yang sangat menguntungkan jika digabungkan, banyak hal positif yang bisa didapatkan dari kegiatan olahraga pariwisata (Suratmin, 2018). Menurut Undang - Undang Republik Indonesia Nomor 3Tahun 2005 tentang Sistem Keolahragaan Nasional, Pasal 1 ayat 12 menyebutkan bahwa olahraga rekreasi adalah olahraga yang dilakukan oleh masyarakat dengan kemauan dan kemampuan yang tumbuh dan berkembang sesuai dengan kondisi dan nilai budaya masyarakat setempat untuk kesehatan, kebugaran dan kesenangan. Oleh karena itu, olahraga dan pariwisata memiliki tujuan yang sama.

Hubungan olahraga dan pariwisata tidak dapat dipisahkan karena keduanya dapat memberikan keuntungan satu sama lain. Bisa saja peristiwa olahraga diselenggarakan di 
daerah wisata dengan tujuan untuk memberikan hiburan tambahan bagi wisatawan, ataupun sebaliknya hanya dimanfaatkan khusus guna menarik wisatawan lokal maupun wisatawan asing (Danasaputra, 2009). Dengan demikian olahraga pun akhirnya dapat memicu bisnis baru seperti tempat hiburan rekreasi, restoran, perhotelan, pengembangan usaha kecil (aksesoris-aksesoris daerah setempat menjadi lebih berkembang), makanan dan minuman khas daerah setempat menjadi lebih dikenal, dan pada akhirnya dapat menciptakan lapangan kerja (Sudiana, 2018)

Kegiatan dalam wisata olahraga dapat berupa kegiatan olahraga aktif yang mengharuskan wisatawan melakukan gerak olah tubuh secara langsung seperti water sport dan kegiatan olahraga pasif dimana wisatawan tidak melakukan gerak olah tubuh, melainkan hanya menjadi penikmat dan pecinta olahraga saja seperti menonton pertandinganmarathon. Pariwisata olahraga memiliki dampak signifikan terhadap kesejahteraan masyarakat. Pariwisata olahraga saat ini mampu mendongkrak popularitas sebuah negara dan membuktikan bahwa Indonesia tidak kalah dengan negara lain, banyak sekali kegiatan disektor pariwisata olahraga diIndonesia. Disisi lain, pembangunan kepariwisataan memerlukan keterlibatan peran serta masyarakat, dan diarahkan untuk memacu peningkatan daya saing global dan pemasukan devisa dengan upaya memajukan pariwisata, antara lain melaluipariwisata olahraga berbasis olahraga air (water sport), karena di negeri kita ini merupakan negara kepulauan jadi sudah terbukti bahwa perairan (maritim) di Indonesia lebih luas dari pada daratan (agraris).

Dalam pelayanan di Gitgit Waterfall bisa dibilang memenuhi standar pengoprasian suatu wahana yang ada, mulai dari sarana dan prasarana pun cukup memadai dan standart, tingkat keamanan permainannya, instruktur juga ada, tidak hanya itu intstruktur juga mendampingi dan mengawasi pada saat kita bermain. Peralatan kemanapun juga sudah memenuhi standart. Selain hal tersebut fasilitas yang lain yang jadi penunjang yaitu kamar ganti, kamar bilas, dan tempat istirahat.

Penelitian analisis potensi pariwisata olahraga di Kabupaten Buleleng. ini perlu untuk dikaji secara menyeluruh dan identifikasi kelemahan serta kelebihan lokasi potensi pariwisata olahraga tersebut. Analisis ini diharapkan dapat membantu dalam pengembangan serta potensi sektor pariwisata olahraga di Kabupaten Buleleng.

\section{Metode}

Penelitian deskriptif merupakan penelitian yang berusaha mendeskripsikan suatu gejala, peristiwa, kejadian yang terjadi saat sekarang. Penelitian deskriptif memusatkan perhatian pada masalah aktual sebagaimana adanya pada saat penelitian berlangsung. Metode penelitian deskriptif adalah penelitian yang berusaha mendeskripsikan atau menggambarkan/melukiskan fenomena atau hubungan antar fenomena yang diteliti dengan sistematis, faktual dan akurat (Kusmayadi \& Sugiarto, 2000:29).

Populasi adalah keseluruhan subyek penelitian (Suharsimi, Arikunto 1998:115). Dalam penelitian ini yang menjadi populasi adalah obyek wisata danwisatawanyang berkunjung ke obyek wisata wahana Canyoning Gitgit Waterfall. Jenis populasinya adalah populasi yang tidak terbatas, yaitu sumber data tidak dapat ditentukan batasannya sehingga relatifnya tidak dapat dinyatakan dalam bentuk jumlah (Hermawan Waristo. 1992:24).

Pengambilan sampel disesuaikan dengan kebutuhan dengan tetap memperhatikan bahwa pengambilan sampel tersebut mewakili reperesentatif untuk dijadikan sampel. Pengambilan sampel dilakukan di lokasi obyek wisata Wahana Canyoning Gitgit Waterfall. Jumlah sampel pada penelitisn ini berjumlah 95 orang

Dalam penelitian ini tenik analisis data yang digunakan adalah teknik analisis data deskriptif dengan menentukan nilai dari skala penilaian katagori dari jawaban responden. Dalam hal ini data dari penelitian akan dianalisis menggunakan teknik statistika deskriptif 
dengan skala penilaian katagori melalui bantuan Microsoft Exel 2010, yaitu data dari angket yang berhasil dikumpulkan kemudian dianalisis dengan menggunakan nilai rata-rata. Analisis tersebut untuk mengetahui persepsi wisatawan terhadap potensi pariwisata olahraga wahana canyoning di Gitgit Waterfall. Instrument yang menggunakan angket terdiri dari pertanyaan positif dan pertanyaan negative, tingkat kesetujuuan menggunakan responden dikasifikasi sebagai berikut : Sangat Setuju (SS), Setuju (S), Tidak Setuju (TS), dan Sangat Tidak Setuju (STS).

Tabel. 1. Skala Penilaian Katagori

\begin{tabular}{cccc}
\hline No & Kriteria & Persentase & Katagori \\
\hline 1. & $\mathrm{Mi}+$ 1.5 SDi, $-<\mathrm{Mi}+3.0 \mathrm{SDi}$ & $81,25 \%-100 \%$ & Sangat Baik \\
2. & $\mathrm{Mi}+$ 0,5 SDi -< $\mathrm{Mi}+$ 1,5 Sdi & $68,75 \%-80 \%$ & Baik \\
3. & $\mathrm{Mi}-0,5 \mathrm{SDi}-<\mathrm{Mi}$ + 0,5 SDi & $56,25 \%-67,5 \%$ & Cukup Baik \\
4. & $\mathrm{Mi}-1,5 \mathrm{SDi}-<\mathrm{Mi}-0,5 \mathrm{SDi}$ & $43,75 \%-55 \%$ & Kurang \\
5. & $\mathrm{Mi}-$ 3.0 SDi $-<\mathrm{Mi}-1.5 \mathrm{SDi}$ & $25 \%-42,5 \%$ & Sangat Kurang \\
\hline
\end{tabular}

Keterangan :

$$
\begin{aligned}
& \text { Jumlah Max = skor max } \mathrm{x} \text { jumlah pernyataan } \\
& =4 \times 20=80 \\
& \text { Jumlah Min }=\text { skor min } \mathrm{x} \text { jumlah pernyataan } \\
& =1 \times 20=20 \\
& \text { Nilai Max }(\%)=\frac{\text { JumlahMax }}{\text { JumlahMax }} \times 100 \\
& =\frac{80}{80} \times 100 \\
& =100 \% \\
& \text { Nilai Min }(\%)=\frac{\text { Jumlah Min }}{\text { JumlahMax }} \times 100 \\
& =\frac{20}{80} \times 100 \\
& =25 \% \\
& =1 / 2 \times(\text { nilai } \max +\text { nilai } \min ) \\
& =1 / 2 \times 125 \\
& =62,5 \\
& =1 / 6 x(\text { nilai } \max -\text { nilai } \min ) \\
& \begin{array}{l}
=1 / 6 \times 75 \\
=12,5
\end{array}
\end{aligned}
$$

\section{Hasil dan Pembahasan}

Pengukuran persepsi wisatawan terhadap potensi pariwisata olahraga wahana Canyoning di Gitgit Waterfall dtelah diukur menggunakan angket yang diidi dalam google form yang terdiri dari 20 butir pertaanyaan. 
Tabel 2. Hasil Analisis

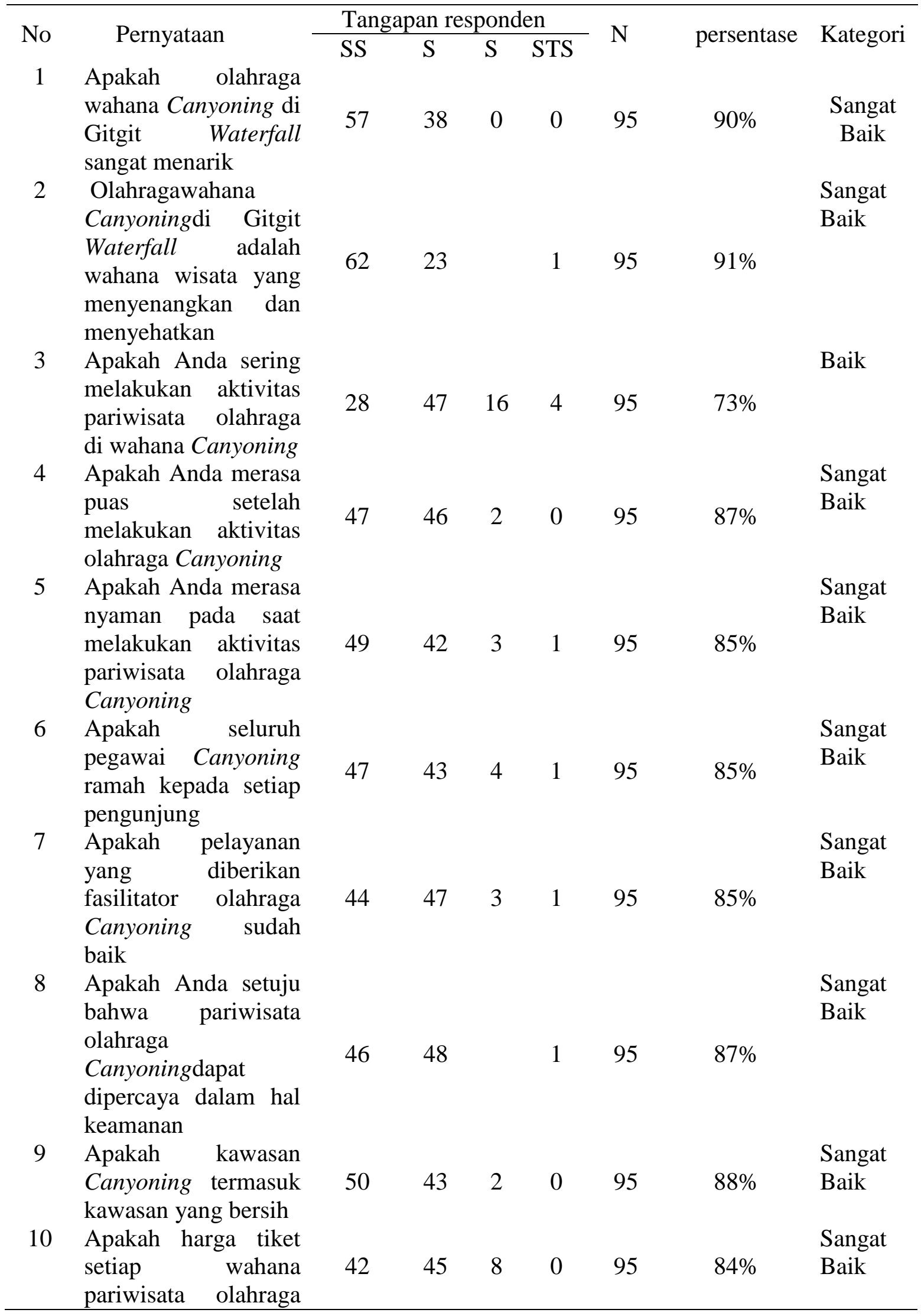




\begin{tabular}{|c|c|c|c|c|c|c|c|c|}
\hline & $\begin{array}{l}\text { terjangkau oleh } \\
\text { semua kalangan }\end{array}$ & & & & & & & \\
\hline 11 & $\begin{array}{l}\text { Apakah fasilitator } \\
\text { pariwisata olahraga } \\
\text { di wahana Canyoning } \\
\text { sangat akrab dengan } \\
\text { para pengunjung }\end{array}$ & 43 & 50 & 2 & 0 & 95 & $86 \%$ & $\begin{array}{l}\text { Sangat } \\
\text { Baik }\end{array}$ \\
\hline 12 & $\begin{array}{l}\text { Apakah kunjungan } \\
\text { Anda karena tertarik }\end{array}$ & 44 & 48 & 3 & 0 & 95 & $86 \%$ & $\begin{array}{l}\text { Sangat } \\
\text { Baik }\end{array}$ \\
\hline 13 & $\begin{array}{l}\text { Apakah fasilitator } \\
\text { pariwisata olahraga } \\
\text { di wahana Canyoning } \\
\text { memiliki pemahaman } \\
\text { yang baik }\end{array}$ & 44 & 49 & 1 & 1 & 95 & $86 \%$ & $\begin{array}{l}\text { Sangat } \\
\text { Baik }\end{array}$ \\
\hline 14 & $\begin{array}{lr}\text { Apakah fasilitator } \\
\text { pariwisata olahraga } \\
\text { di wahana wisata } \\
\text { Canyoningmemiliki } \\
\text { komunikasi yang } \\
\text { baik }\end{array}$ & 43 & 49 & 2 & 1 & 95 & $85 \%$ & $\begin{array}{l}\text { Sangat } \\
\text { Baik }\end{array}$ \\
\hline 15 & $\begin{array}{l}\text { Apakah fasilitator } \\
\text { pariwisata olahraga } \\
\text { di } \\
\text { Canyoningmenarik } \\
\text { dan berwibawa }\end{array}$ & 41 & 52 & 2 & 0 & 95 & $85 \%$ & $\begin{array}{l}\text { Sangat } \\
\text { Baik }\end{array}$ \\
\hline 16 & $\begin{array}{lr}\text { Apakah fasilitator } \\
\text { pariwisata } & \text { olahraga } \\
\text { di wahana } & \text { Canyoning } \\
\text { menguasai } & \text { masalah } \\
\text { teknis } & \text { pelatihan } \\
\text { termasuk masalah } & \text { keselamatan }\end{array}$ & 45 & 50 & 0 & 0 & 95 & $87 \%$ & $\begin{array}{l}\text { Sangat } \\
\text { Baik }\end{array}$ \\
\hline 17 & $\begin{array}{l}\text { Apakah sarana dan } \\
\text { prasarana pariwisata } \\
\text { olahraga di wahana } \\
\text { Canyoning masih } \\
\text { layak dan memenuhi } \\
\text { standar }\end{array}$ & 47 & 46 & 2 & 0 & 95 & $87 \%$ & $\begin{array}{l}\text { Sangat } \\
\text { Baik }\end{array}$ \\
\hline 18 & $\begin{array}{l}\text { Apakah sarana dan } \\
\text { prasarana pariwisata } \\
\text { olahraga memiliki } \\
\text { kelengkapan yang } \\
\text { baik }\end{array}$ & 47 & 47 & 1 & 0 & 95 & $87 \%$ & $\begin{array}{l}\text { Sangat } \\
\text { Baik }\end{array}$ \\
\hline 19 & $\begin{array}{l}\text { Apakah anda sering } \\
\text { berkunjung di } \\
\text { wahana Canyoning }\end{array}$ & 32 & 47 & 14 & 2 & 95 & $77 \%$ & Baik \\
\hline 20 & $\begin{array}{l}\text { Pariwisata olahraga } \\
\text { di Canyoning } \\
\text { sudah baik }\end{array}$ & 49 & 46 & 0 & 0 & 95 & $88 \%$ & $\begin{array}{l}\text { Sangat } \\
\text { Baik }\end{array}$ \\
\hline
\end{tabular}


Keterangan:

SS : Sangat Setuju

S : Setuju

TS : Tidak Setuju

STS : Sangat Tidak Setuju

N : Jumlah Responden

Tabel 3. Hasil Analisis Deskriptif

\begin{tabular}{llllc}
\hline NO & Indikator & Jumlah responden & persentase & Kategori \\
\hline 1 & Faktor Intrinsik & 95 & $85,9 \%$ & Sangat Baik \\
2 & Faktor Ekstrinsik & 95 & $84,6 \%$ & Sangat Baik \\
3 & Faktor sarana dan & 95 & $87 \%$ & Sangat Baik \\
& prasarana & & & \\
\hline
\end{tabular}

Berdasarkan hasil analisis data dari tabel 3. Persepsi wisatawan terhadap potensi pariwisata olahraga wahana canyoning di gitgit waterfall di kabupaten Buleleng memperoleh persentase dengan sebagai berikut :

$$
\begin{aligned}
\text { Rumus } & =\frac{\bar{X} 1+\bar{X} 2+\bar{X} 3}{3} \\
& =\frac{85,9 \%+84,6 \%+87,0 \%}{3} \\
& =85,5 \%
\end{aligned}
$$

Keterangan :

$\mathrm{X} 1=$ Nilai persentase persepsi intrinsik

$\mathrm{X} 2=$ Nilai persentase persepsi ekstrinsik

$\mathrm{X} 3=$ Nilai persentase sarana prasarana

\section{Simpulan}

Daya tarik wisatawan terhadap olahraga wahana canyoning sangat baik. Wisatawan berpendapat positif dan memahami potensi alam yang disajikan dan dikemas dalam wahana canyoning di Gitgit Waterfall, sehingga selain itu untuk meningkatkan potensi pariwisata olahraga dan peningkatan potensi alam yang ada di Buleleng juga untuk kedepannya masyarakat/wisatawan, pengelola, pemerintah tahu bahwa potensi alam yang ada di Buleleng kususnya di Gitgit harus dikembangkan karena hal tersebut bisa mendongkrak popularitas suatu daerah.

Wisatawan mendapat informasi secara cepat, menarik tertuju, baik menggunakan media sosial (instagram, facebook dan media sosial lainnya) adapun media pemasaran lain (pampfet, benner, dan media cetak) yang bertujuan untuk memperkenalkan kepada masyarakat mengenai potensi, daya tarik, serta wahana yang disajikan. Tetapi beberapa media yang digunakan untuk promosi media sosial sangat berpengaruh dalam penyampaian informasi yang akan disampaikan kepada wisatawan karena sangat mudah untuk diakses meningkatkan minat berkunjung ke Gitgit Waterfall. 


\section{Daftar Pustaka}

Devy, H. A. (2017). Pengembangan Obyek Dan Daya Tarik Wisata Alam Sebagai Daerah Tujuan Wisata Di Kabupaten Karanganyar. . Jurnal Sosiologi DILEMA, 32(1).

Purwita, P. U. (2018). Pengembangan Potensi Pantai Lovina Sebagai Ekowisata Pesisir Di Desa Kalibukbuk, Kabupaten Buleleng, Bali. Jurnal Destinasi Pariwisata, 6(1).

Sahara, F. N. A. (2016). Analisis Motivasi Berkunjung Wisatawan Dan Tingkat Pengetahuan Wisatawan Tentang Produk Industri Kreatif Sektor Kerajinan. Jurnal Administrasi Bisnis (JAB)|, 35(2).

Sudiana, I. K. (2018). Dampak Olahraga Wisata Bagi Masyarakat. Jurnal IKA, 16(1).

Suratmin. (2018). Pengantar Olahraga Rekreasi dan Sport tourism. Depok: PT Rajagrafindo Persada.

Sutiani, N. W. (2018). Peranan Desa Wisata Dalam Pembangunan Desa Di Desa Munduk Kecamatan Banjar Kabupaten Buleleng. Jurnal Cakrawarti, 1(2).

Widiastini, N. M. A. (2012). Strategi Pemasaran Pariwisata Di Kabupaten Buleleng, Bali. Jurnal Ilmu Sosial Dan Humaniora, 1(1).

Yanti, A. A. I. E. K. (2021). Community Based Tourism dalam Menyongsong New Normal Desa Wisata Bali. Jurnal Komunikasi Hukum, 7(1). 